\title{
Characterization and Identification of Proteolytic Bacteria from the Gut of the Velvetbean Caterpillar (Lepidoptera: Noctuidae)
}

\author{
Author(s): L. E. Visôtto, M.G.A. Oliveira, A.O.B. Ribon, T. R. Mares-Guia, and
}

R.N.C. Guedes

Source: Environmental Entomology, 38(4):1078-1085.

Published By: Entomological Society of America

https://doi.org/10.1603/022.038.0415

URL: http://www.bioone.org/doi/full/10.1603/022.038.0415

BioOne (www.bioone.org) is a nonprofit, online aggregation of core research in the biological, ecological, and environmental sciences. BioOne provides a sustainable online platform for over 170 journals and books published by nonprofit societies, associations, museums, institutions, and presses.

Your use of this PDF, the BioOne Web site, and all posted and associated content indicates your acceptance of BioOne's Terms of Use, available at www.bioone.org/page/terms_of_use.

Usage of BioOne content is strictly limited to personal, educational, and non-commercial use. Commercial inquiries or rights and permissions requests should be directed to the individual publisher as copyright holder. 


\title{
Characterization and Identification of Proteolytic Bacteria From the Gut of the Velvetbean Caterpillar (Lepidoptera: Noctuidae)
}

\author{
L. E. VISÔTTO, ${ }^{1}$ M.G.A. OLIVEIRA, ${ }^{1,2}$ A.O.B. RIBON, ${ }^{1}$ T. R. MARES-GUIA ${ }^{3,4}{ }^{2}$ AND R.N.C. GUEDES ${ }^{5}$
}

Environ. Entomol. 38(4): 1078-1085 (2009)

\begin{abstract}
The characterization and identification of proteolytic bacteria from the gut of the velvetbean caterpillar (Anticarsia gemmatalis) were the objectives of this study. Twelve aerobic and anaerobic isolates of proteolytic bacteria were obtained from the caterpillar gut in calcium caseinate agar. The number of colony forming units (CFUs) of proteolytic bacteria was higher when the bacteria were extracted from caterpillars reared on artificial diet rather than on soybean leaves $(1.73 \pm 0.35 \times$ $10^{3}$ and $0.55 \pm 0.22 \times 10^{3} \mathrm{CFU} / \mathrm{mg}$ gut, respectively). The isolated bacteria were divided into five distinct groups, according to their polymerase chain reaction-restriction fragment-length polymorphism profiles. After molecular analysis, biochemical tests and fatty acid profile determination, the bacteria were identified as Bacillus subtilis, Bacillus cereus, Enterococcus gallinarum, Enterococcus mundtii, and Staphylococcus xylosus. Bacterial proteolytic activity was assessed through in vitro colorimetric assays for (general) proteases, serine proteases, and cysteine proteases. The isolated bacteria were able of hydrolyzing all tested substrates, except Staphylococcus xylosus, which did not exhibit serine protease activity. This study provides support for the hypothesis that gut proteases from velvetbean caterpillar are not exclusively secreted by the insect cells but also by their symbiotic gut bacteria. The proteolytic activity from gut symbionts of the velvetbean caterpillar is suggestive of their potential role minimizing the potentially harmful consequences of protease inhibitors from some of this insect host plants, such as soybean, with implications for the management of this insect pest species.
\end{abstract}

KEY WORDS bacteria symbionts, proteases, 16S rRNA, protease inhibitor, pest control

Proteases are one of the main enzyme classes involved in the digestion of the velvetbean caterpillar Anticarsia gemmatalis Hübner (Lepidoptera: Noctuidae), a key pest of soybean. Among digestive proteases, serine and cysteine proteases are the most studied and characterized, not only in A. gemmatalis (Oliveira et al. 2005, Xavier et al. 2005), but also in other insect species from different orders (Reeck et al. 1999, Terra and Ferreira 2005).

The use of protease inhibitors (PIs) as an alternative method for pest control is currently under intensive investigation (Pompermayer et al. 2001, Pilon et al. 2006). However, the velvetbean caterpillar is able to bypass the effects caused not only by natural inhibitors found in soybean plants (Soybean trypsin inhibitor [SBT] and Bowman-Birk-inhibitor [BBI]), but also by synthetic trypsin-like inhibitors such as benzamidine (Pilon et al. 2006). The digestive (trypsin-like) serine

\footnotetext{
${ }^{1}$ Departamento de Bioquímica e Biologia Molecular, Instituto de Biotecnologia Aplicada a Agropecuária (BIOAGRO), Universidade Federal de Viçosa, Viçosa, MG 36571-000, Brazil.

${ }^{2}$ Corresponding author, e-mail: malmeida@ufv.br.

${ }^{3}$ Departamento de Bioquímica, Instituto de Química, Universidade de São Paulo, São Paulo, SP 05508-900, Brazil.

${ }^{4}$ Núcleo de Terapia Celular e Molecular (NUCEL), Universidade de São Paulo, São Paulo, SP 05508-900, Brazil.

${ }^{5}$ Departamento de Biologia Animal, Universidade Federal de Viçosa, Viçosa, MG 36571-000, Brazil.
}

proteases purified from the velvetbean caterpillar are sensitive to inhibition by soybean protease inhibitors, as well as other serine protease inhibitors such as aprotinin and benzamidine (Oliveira et al. 2005, Xavier et al. 2005), but the caterpillars are still able to circumvent such host defense (Pilon et al. 2006, Fortunato et al. 2007). This versatility could arise from changes in protease expression in the caterpillars but also from enzymes synthesized by resident bacteria from their intestinal tract. Insect gut symbionts may contribute to host nutrition by producing enzymes, increasing digestion efficiency and supplying amino acids and vitamins (Cruden and Markovetz 1987, Brennan et al. 2004). However, the emphasis on most studies assessing the digestive role of insect gut bacteria is in carbohydrate (and sometimes lipid) degradation, rather than protein degradation, with few exceptions (Walker et al. 1999). In addition, little is known regarding the functional role of these microorganisms associated with Lepidoptera, despite recent advances with the diamondback moth (Yponomeutidae) and plant-promoting traits of its symbiont bacteria (Indiragandhi et al. 2007, 2008).

Gut bacteria from the velvetbean caterpillar may produce digestive proteases and, if so, such proteases may play a role in its adaptation to protease inhibitors, which have not yet received attention. Therefore, we 
reported here the isolation and characterization of gut bacteria from the velvetbean caterpillar. The proteolytic activity of the isolated gut bacteria was also determined aiming to provide preliminary evidence of their potential involvement on caterpillar protein digestion and possible role in allowing the adaptation of this insect pest species to protease inhibitors from its host plant.

\section{Materials and Methods}

Insects. The colony of the velvetbean caterpillar was established from eggs obtained from the laboratory colony maintained at the Soybean National Research Center of the Brazilian Agricultural Research Corporation (CNP Soja, EMBRAPA, Londrina, Brazil) on the same artificial diet used in our experiments (Hoffman-Campo et al. 1985). The insect eggs were surface-sterilized with UV light and subsequently transferred to plastic containers in a laminar flow chamber. After egg hatching, the caterpillars were place in plastic jars (500 ml; five caterpillars per jar), and four batches of five caterpillars each were reared on artificial diet throughout their development, whereas another four batches of five caterpillars were reared on soybean leaves (also throughout their development). The artificial diet used was protein rich and made of beans, soybean protein, casein, yeast, and wheat germ, enriched with ascorbic acid and complex B vitamins (Hoffman-Campo et al. 1985). The leaves used for rearing the caterpillars were obtained from previously unwounded soybean plants (Glycine max L. Merr. cultivar CAC1) at the V4 developmental stage, which were cultivated in greenhouse conditions $\left(20-30^{\circ} \mathrm{C}\right)$, irrigated twice a day, and fertilized with $\mathrm{N}-\mathrm{P}-\mathrm{K}$ and $\mathrm{Ca}(50,200,100$, and $100 \mathrm{ppm}$, respectively). The leaf petiole was involved in wet cotton when harvested for the caterpillars to retain humidity. Both diets were provided ad libitum to the respective insect batches. The caterpillars were reared in this two-diet system under controlled environmental conditions $\left(25 \pm 5^{\circ} \mathrm{C}, 70 \pm 10 \% \mathrm{RH}\right.$, and 14:10 [L:D] photoperiod) until reaching the fifth instar. All reagents were purchased from Sigma-Aldrich Química Brasil (São Paulo, Brazil), except ascorbic acid, which was purchased from Synth-LabSynth (São Paulo, Brazil). Beans, yeast, wheat germ, soybean protein, and vitamins were all obtained from the local market.

Isolation of Proteolytic Bacteria. Fifth-instar larvae reared either with diet or soybean leaves were collected and chilled at $-18^{\circ} \mathrm{C}$ for 2 min to slow down metabolism. The insects were subsequently surface sterilized in $70 \%$ ethanol. To isolate anaerobic bacteria, three batches of five caterpillars each were dissected in an anaerobic chamber (Coy Laboratory Products, Grass Lake, MI), and their whole guts were inoculated in calcium caseinate agar. The petri dishes were maintained under $\mathrm{CO}_{2}: \mathrm{H}_{2}$ (95:5\%) atmosphere at $30^{\circ} \mathrm{C}$. To isolate aerobic bacteria, the caterpillars were dissected in a biosafety cabinet and also inoculated in calcium caseinate agar. All inoculations were performed in triplicate. After $48 \mathrm{~h}$, colonies that formed clear zones caused by proteolysis were selected and inoculated in Luria-Bertaini agar until pure colonies were obtained.

Genomic DNA Extraction, Amplification, and Restriction Fragment-Length Polymorphism Analysis. The isolated proteolytic bacteria were inoculated in 3 $\mathrm{ml}$ of brain heart infusion (BHI) broth at $37^{\circ} \mathrm{C}$ for $16 \mathrm{~h}$ and centrifuged at $400 \mathrm{~g}$. The cultures were centrifuged at $13,400 \mathrm{~g}$ for $5 \mathrm{~min}$. The pellets were submitted to DNA extraction following Pospiech and Neumann (1995). These DNA samples were amplified with primers for the 16S rRNA: 5'-AGAGTTTGATCMTGG-3' (16SF) and 5'-TACCTTGTTACGACTT-3' (16SR), and the products were analyzed by polymerase chain reaction (PCR)-restriction fragment-length polymorphism (RFLP). The amplification reactions were performed in $25 \mu \mathrm{l}$, containing: $2.5 \mathrm{mM} \mathrm{MgCl}_{2}$, Taq polymerase buffer $1 \times, 200 \mu \mathrm{M}$ deoxyribonucleotides, $0.4 \mu \mathrm{M}$ of each primer, $1 \mathrm{U}$ of Taq polymerase, and $50 \mathrm{ng} / \mu \mathrm{l}$ DNA. The amplification program consisted of initial denaturing at $94^{\circ} \mathrm{C}$ for $2 \mathrm{~min}$, followed by 35 cycles of denaturation $\left(1 \mathrm{~min}\right.$ at $\left.94^{\circ} \mathrm{C}\right)$, annealing $\left(1 \mathrm{~min}\right.$ at $\left.50^{\circ} \mathrm{C}\right)$, and extension $\left(2 \mathrm{~min}\right.$ at $\left.72^{\circ} \mathrm{C}\right)$, followed by a final extension step $\left(5 \mathrm{~min}\right.$ at $\left.72^{\circ} \mathrm{C}\right)$. A $25-\mu \mathrm{l}$ aliquot was incubated with $5 \mathrm{U}$ of HaeIII and RsaI restriction enzymes (Promega, Madison, WI). Based on their restriction profiles, different isolates were selected for identification and proteolytic activity evaluation.

Sequencing of the 16S rRNA and Sequence Analysis. The PCR products were extracted from the agarose gel $(0.8 \%)$ with the QIAquick Gel Extraction Kit (Qiagen, Valencia CA), following the manufacturer's instructions. The DNA extraction from the gel was carried out to secure cleaner DNA fragments for the sequencing, free of dNTPs, primer remains, etc., which would be present if PCR amplicon were directly used. The amplicons were sequenced in a MegaBACE 500 equipment (GE Healthcare, São Paulo, Brazil) using the following 16S rRNA primers: 5'-AGAGTTTGATCMTGG-3' (16SF) and 5' -TACCTTGTTACGACTT-3' (16SR). The sequences were compared with the GenBank DNA sequence database, using the program BLASTn.

Biochemical Characterization of the Isolated Bacteria. The bacterial isolates were characterized by Gram staining and biochemical tests, according to bacteria identification protocols described by Sneath et al. (1986). Fatty acid methyl ester (FAME) analysis was performed to identify Bacillus species. The Bacillus were grown in trypticase soy agar (TSA) at $30^{\circ} \mathrm{C}$ for $24 \mathrm{~h}$. FAMEs were extracted with the Instant FAME kit (MIDI, Newark, DE). Samples were analyzed by gas chromatography in an Agilent 7890 chromatographer. The results were compared with the ITSA 1.0 reference database.

Protein Determination and Enzyme Assays. Protein determination was performed following Bradford (1976), using bovine serum albumin (BSA) solutions as standards. Proteolytic bacteria were cultivated in 50 $\mathrm{ml} \mathrm{BHI}$ at $37^{\circ} \mathrm{C}$ for $48 \mathrm{~h}$ at $400 \mathrm{~g}$. After incubation, the cultures were centrifuged at $13,400 \mathrm{~g}$ for $10 \mathrm{~min}$ at $4^{\circ} \mathrm{C}$. 
Table 1. Total and proteolytic bacteria (no. CFUs \pm SEM) found in the intestinal tract of $A$. gemmatalis reared with artificial diet or soybean leaves

\begin{tabular}{lccc}
\hline \multirow{2}{*}{ Diet } & \multicolumn{2}{c}{ Total bacteria $(\mathrm{CFU} / \mathrm{mg}$ of gut tissue) } & \multicolumn{2}{c}{ Proteolytic bacteria $(\mathrm{CFU} / \mathrm{mg}$ of gut tissue) } \\
\cline { 2 - 3 } & Aerobiosis & Anaerobiosis & Aerobiosis \\
\hline Articial diet & $45.20 \pm 2.27 \times 10^{3}$ & $5.19 \pm 0.32 \times 10^{3}$ & $1.73 \pm 0.35 \times 10^{3}$ \\
Soybean leaves & $36.78 \pm 2.50 \times 10^{3}$ & $3.00 \pm 0.23 \times 10^{3}$ & $0.00 \pm 0.00$ \\
\hline
\end{tabular}

The supernatants were collected and used in the enzyme assays. Gereral proteolytic activity was determined using $2 \%$ azocasein as substrate following Kunitz (1947), as adapted by Oliveira et al. (2005). Serine protease activity was determined following Erlanger et al. (1961) using the chromogenic substrate $\mathrm{N}$-benzoyl-L-arginine $p$-nitroanilide (L-BApNA) to a final concentration of $0.5 \mathrm{mM}$. Cysteine protease activity was determined in the same conditions used for serine protease activity determination, but with the addition of $1 \mathrm{mM}$ benzamidine, a serine protease inhibitor, and $5 \mathrm{mM}$ dithiothreitol. All enzymatic assays were performed in triplicate.

Statistical Analyses. Results of colony forming units (CFUs) of gut bacteria isolated from the velvetbean caterpillar were subjected to two-way ( 2 diets $\times 2$ incubation systems) analysis of variance (ANOVA; PROC GLM; SAS Institute 2002). Results of enzyme activity of the five bacterial isolates were subjected to ANOVAs followed by Tukey's honestly significant difference (HSD) test $(P<0.05)$, when appropriate (PROC GLM; SAS Institute 2002). Assumptions of normality and homogeneity of variance were checked (PROC UNIVARIATE; SAS Institute 2002), but no data transformation was necessary.

\section{Results}

Isolation and Colony Formation of Gut Bacteria. The results of number of CFUs of gut bacteria obtained from velvetbean caterpillars are shown in Table 1. The ANOVA for CFUs of gut bacteria indicated that caterpillar rearing diet (artificial diet versus soybean leaves) significantly affected the CFUs of both total $\left(F_{1,11}=9.70, P=0.01\right)$ and proteolytic bacteria $\left(F_{1,4}=\right.$ $7.00, P=0.04)$, with significantly more colonies formed when the bacteria were extracted from caterpillars reared on artificial diet $\left(25.93 \pm 9.01 \times 10^{3}\right.$ and $1.73 \pm 0.35 \times 10^{3} \mathrm{CFU} / \mathrm{mg}$ gut for total and proteolytic bacteria, respectively) compared with bacteria from caterpillars reared on soybean leaves $\left(19.89 \pm 7.36 \times 10^{3}\right.$ and $0.55 \pm 0.22 \times 10^{3} \mathrm{CFU} / \mathrm{mg}$ gut for total and proteolytic bacteria, respectively). Bacteria colony formation was $\sim 10$ times higher under aerobic condition $\left(40.99 \pm 4.21 \times 10^{3} \mathrm{CFU} / \mathrm{mg}\right.$ gut $)$ than under anaerobic conditions $\left(4.09 \pm 0.52 \times 10^{3}\right.$ $\mathrm{CFU} / \mathrm{mg}$ gut $)$ for total bacteria $\left(F_{1,11}=469.22, P<\right.$ 0.0001 ). There was no significant interaction between caterpillar diet and aerobiosis/anaerobiosis for total bacteria isolated from the caterpillar gut $\left(F_{1,11}=3.35\right.$, $P=0.10)$. No proteolytic bacteria were detected under anaerobic conditions. Twelve morphologically distinct proteolytic bacteria were isolated-seven from the gut of caterpillars reared on artificial diet and five from the gut of caterpillars reared on soybean leaves.

RFLP Analysis of PCR-Amplified 16S rRNA. The results of the PCR-RFLP analysis are shown in Fig. 1. Figure 1A shows the DNA samples after cleavage with the restriction enzyme HaeIII. Samples with the same restriction profile were cleaved with the enzyme RsaI to ensure that these bacteria pertain to the same group (Fig. 1B). Five distinct groups were found, based on the different restriction profiles: group 1 (isolate 1), group 2 (isolates 2,5 , and 7 ), group 3 (isolates 3,8 , and 11 ), group 4 (isolates 4 and 6 ), and group 5 (isolates 9,10 , and 12). Based on these results, one isolate from each group was selected for further characterization.

Sequence Analysis of the 16S rRNA, Biochemical Characterization, and Identification. Isolate identification was performed by sequencing the 16S rRNA gene of one member of each group of bacterial isolates. The PCR products generated sequences of $\approx 1,400 \mathrm{bp}$. Molecular analysis allowed the identification of all bacteria (Table 2). Molecular identification was confirmed based on results from morphological, biochemical (Table 3), and membrane fatty acid analyses. Isolates from groups 1 and 2 were respectively identified as Bacillus subtilis and Bacillus cereus, based on their fatty acid profile (data not shown) and on the following observed parameters: rod-shaped morphology, aerobiosis, mobility, and catalase positivity. Groups 3 and 4 were identified as group D Streptococcus (Enterococcus) with the shape of gram-positive diplococci. These isolates were able to perform esculin hydrolysis in the presence of $40 \%$ bile and to grow in $6.5 \% \mathrm{NaCl}$. Finally, motility and pigmentation tests allowed isolates from groups 3 and 4 to be identified as Enterococcus mundtti and Enterococcus gallinarum, respectively. The isolate from group 5 exhibited characteristics of staphylococci: shape of irregularly grouped cocci, positive for catalase, negative for oxidase, and resistance to bacitracin. Furthermore, this isolate was identified as a member of Staphylococcus sp. group because of its negativity for coagulase, resistance to novobiocin, and acid production from $\mathrm{xy}$ losis, which finally identified this isolate as S. xylosus.

Enzymatic Assays. Total protease, serine protease, and cysteine protease activities were determined in the supernatants from bacterial cultures and are depicted in Fig. 2. ANOVA performed to compare the proteolytic activity of the different bacteria isolates indicated significant differences among them for all tested substrates (general proteases: $F_{4,10}=8.46, P=0.003$; serine proteases: $F_{4,10}=20.76$, $P<0.0001$; cysteine protease: $F_{4,10}=6.65, P=$ 


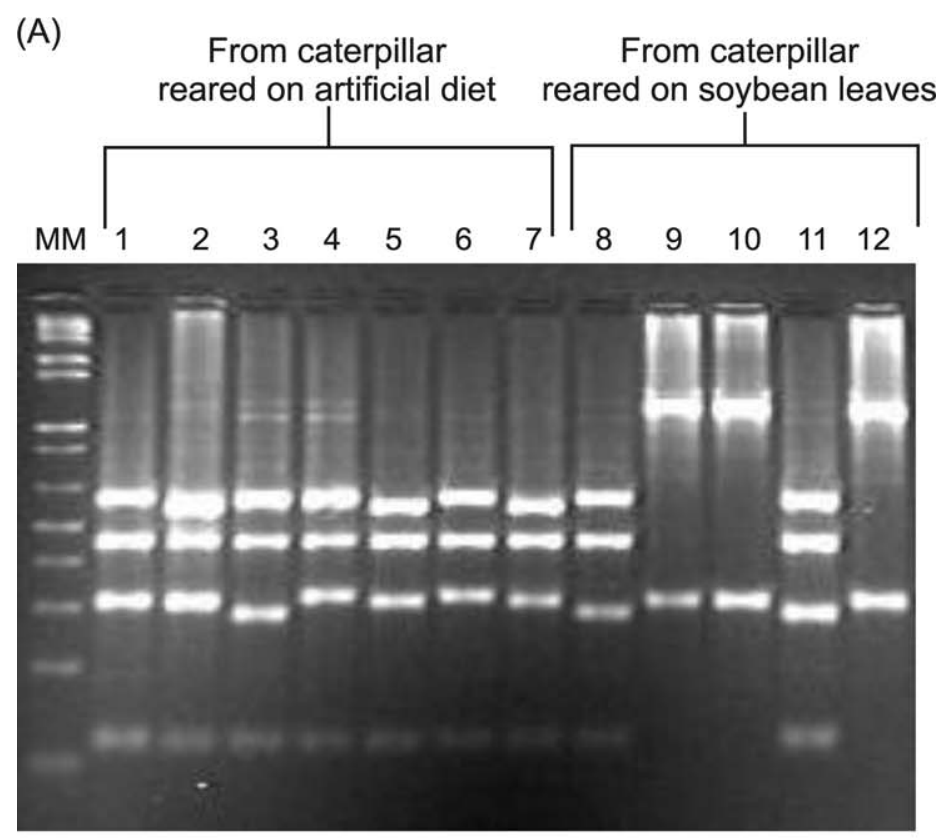

(B)

\section{Groups of gut bacteria isolates}
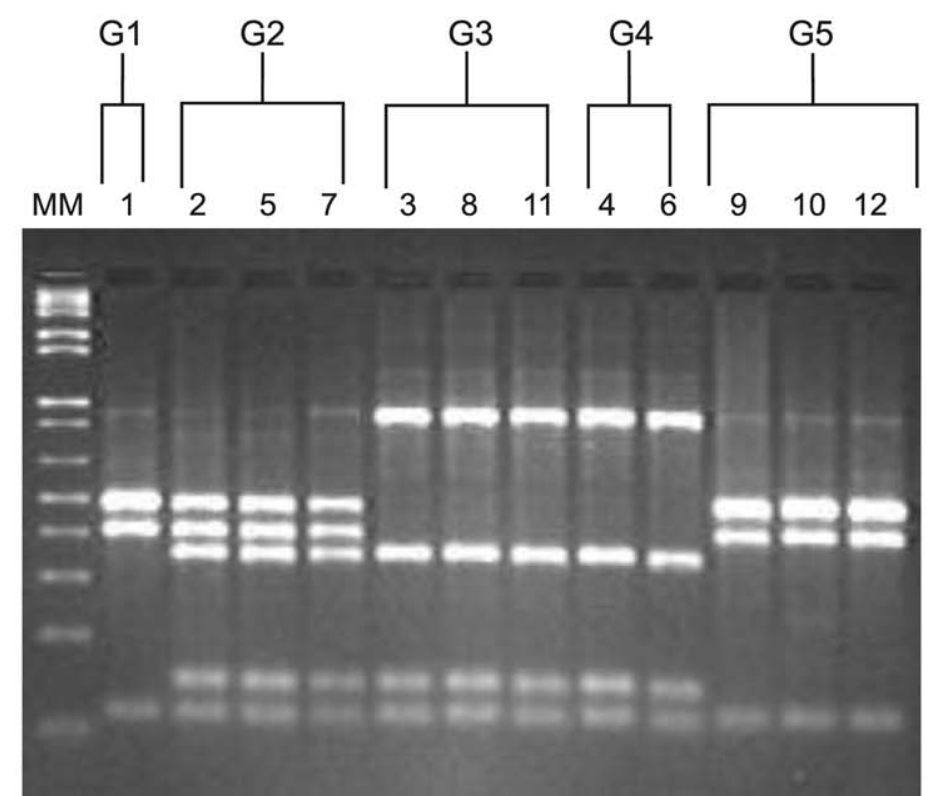

Fig. 1. PCR-RFLP analysis of the 16S rRNA gene of bacteria isolated from the gut of the velvebean caterpillar (A. gemmatalis). The restriction profiles were obtained after sample digestion with the restriction enzymes HaeIII (A) and Rsal (B). Lane MM contains the molecular mass standards, and lanes 1-12 refer to each proteolytic isolate. The isolates obtained from caterpillars reared on each diet are indicated in A, whereas the isolate groups (G1, G2, G3, G4, G5) are indicated in B.

0.007). The bacterial species isolated were capable of hydrolyzing all substrates, except S. xylosus, which did not exhibit serine protease activity. E. mundtti exhibited the highest proteolytic activity, whereas B. cereus exhibited the highest serine and cysteine protease activities.

\section{Discussion}

Insect gut microbiota is greatly influenced by insect diet (Walker et al. 1999). Bacteria found in the artificial diet and in soybean leaves are ingested by $A$. gemmatalis, and the finding of bacterial symbionts 
Table 2. Identification of the bacterial groups isolated from the gut of the velvetbean caterpillar (A. gemmatalis) based on the $16 \mathrm{~S}$ rRNA gene

\begin{tabular}{lcccc}
\hline \hline \multirow{2}{*}{ Molecular analysis } & \multicolumn{3}{c}{ Bacterial groups } \\
\cline { 2 - 5 } & 1 & 2 & 3 & 4 \\
\hline Number of sequenced bases & 1,419 & 329 & 1,337 & 1,408 \\
Similarity (\%) & $97 \%$ & $91 \%$ & $99 \%$ & $99 \%$ \\
GenBank accession number & EU569316 & EU569317 & EU569314 & EU569315 \\
Identification & Bacillus subtilis & Bacillus cereus & Enterococcus mundtii & Enterococcus gallinarum \\
\hline
\end{tabular}

associated with the gut of this insect species is expected. Although we do not have direct evidence that the isolated bacteria originated from the insect diet, such a possibility is very high because potential contamination from other sources was minimized during the bacterial isolation. Our results indicate significant differences in CFUs of gut bacteria from caterpillars reared on artificial diet (higher) and soybean leaves (lower). This is probably because of the higher protein content present in the artificial diet, which favors the development of proteolytic bacteria.

The gut bacteria isolated from the velvetbean caterpillar were mainly aerobic, particularly the proteolytic bacteria, although the low levels of $\mathrm{O}_{2}$ encountered in the insect gut allow the survival of facultative anaerobic bacteria. However, as the intestinal tract of A. gemmatalis exhibits a relatively simple compartimentalization, its microenvironment is probably not fully anoxic because of a higher $\mathrm{O}_{2}$ flow potentially allowing the development of both aerobic and facultative anaerobic bacteria. This is a contrast with the termite gut, which exhibits a prevailing anoxic atmosphere favoring the development of anaerobic microorganisms (Brune and Friedrich 2000). Although the prevalence of aerobic and facultative anaerobic bacteria in the caterpillar gut is plausible, the culture medium used in our study may also lack nutritional compounds required for the growth of the anaerobic gut bacteria explaining the lower numbers of their CFUs. In addition, our culture media, which is suitable for detection of proteolytic bacteria, does not

Table 3. Morphological and biochemical properties of the bacterial groups isolated from the gut of the velvetbean caterpillar ( $A$. gemmatalis)

\begin{tabular}{|c|c|c|c|c|c|c|c|c|c|c|}
\hline \multirow{2}{*}{ Traits } & \multicolumn{10}{|c|}{ Bacterial groups } \\
\hline & & 1 & & 2 & & 3 & & 4 & & 5 \\
\hline Morphology & Rod & & Rod & & Cocci & & Cocci & & Cocci & \\
\hline Gram staining & & + & & + & & + & & + & & + \\
\hline Arrangement & Single & & Single & & Diplococc & & Diplococci & & Groups & \\
\hline Motility & & + & & + & & - & & + & & - \\
\hline Oxidation & & - & & - & & - & & - & & - \\
\hline Catalase test & & + & & + & & - & & - & & + \\
\hline Coagulase test & & - & & - & & - & & + & & - \\
\hline Hemolysis & $\beta$ & & $\beta$ & & $\alpha$ & & $\alpha$ & & $\alpha$ & \\
\hline Camp test & ND & & ND & & & - & & - & & - \\
\hline $\mathrm{NaCl} 6.5 \%$ tolerance & & + & & + & & + & & + & & + \\
\hline Esculine hydrolysis & & + & & - & & + & & + & & - \\
\hline MacConkey growth & & + & & - & & - & & - & & - \\
\hline Pigment on tryptic soy agar & ND & & ND & & & + & & - & ND & \\
\hline \multicolumn{11}{|l|}{ Acid production of carbohydrates } \\
\hline L-arabinose & & + & & + & & + & & + & & + \\
\hline Cellobiose & & + & & - & & - & & - & & - \\
\hline Fructose & & + & & + & & + & & + & & + \\
\hline Glucose & & + & & + & & + & & + & & + \\
\hline Lactose & & - & & - & & + & & + & & - \\
\hline Maltose & & - & & + & & - & & + & & + \\
\hline D-mannitol & & + & & - & & + & & + & & + \\
\hline D-mannose & & - & & - & & - & & - & & + \\
\hline D-melibiose & & + & & + & & + & & + & & + \\
\hline Raffinose & & + & & + & & - & & + & & - \\
\hline Ribose & & - & & - & & + & & + & & - \\
\hline Sorbitol & ND & & ND & & & + & & + & ND & \\
\hline Sorbose & ND & & ND & & & - & & - & ND & \\
\hline Sucrose & & + & & + & & + & & + & & + \\
\hline D-trehalose & & + & & + & & + & & + & & + \\
\hline D-xylose & & - & & - & & + & & - & & + \\
\hline Bacitracin $(0.04 \mathrm{U})$ & ND & & ND & & $\mathrm{R}$ & & $\mathrm{R}$ & & $\mathrm{R}$ & \\
\hline Novobiocin $(5 \mu \mathrm{g})$ & ND & & ND & & ND & & ND & & $\mathrm{R}$ & \\
\hline Vancomycin $(30 \mu \mathrm{g})$ & ND & & ND & & $\mathrm{S}$ & & $\mathrm{S}$ & & $\mathrm{S}$ & \\
\hline Identification & Bacillu & is subtilis & Bacillu & us cereus & Enterococc & cus mundtii & Enterococcu & us gallinarum & Staphyloce & occus xylosus \\
\hline
\end{tabular}

ND, not determined; R, resistant; S, susceptible. 

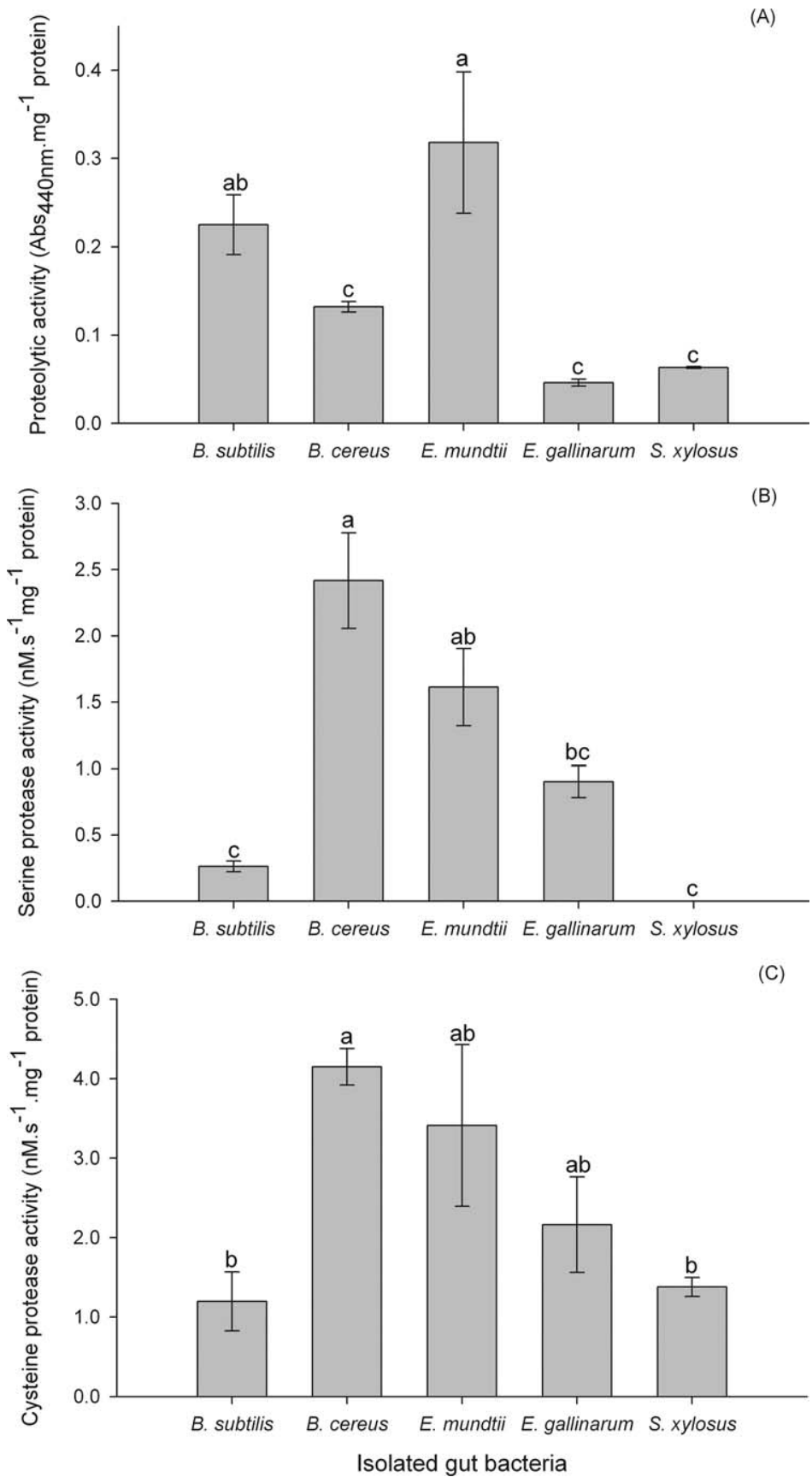

Fig. 2. Specific activity of general proteases (A), serine proteases (B), and cysteine proteases (C) determined in the supernatants of bacterial cultures. Each histogram bar represents the mean of three replicates. The vertical bars represent SEM. Histogram bars with the same letter are not significantly different by Tukey's HSD test $(P<0.05)$.

allow assessing of the entire cultivable bacteria community.

The morphological and biochemical characterizations of the isolated gut bacteria from the velvetbean caterpillar, together with the PCR-RFLP analysis, showed the presence of only five different species of proteolytic bacteria. Among the bacteria isolated, $\mathrm{Ba}$ - cillus is the genus most commonly found in insect guts (Wenzel et al. 2002, Ertürk and Demirbag 2006), and some Bacillus species are pathogenic to insects and used as biological control agents of insect pests (Ertürk and Demirbag 2006). Enterococcus has also been reported in the gut of fruit flies (Kuzina et al. 2001), houseflies (Macovei and Zurek 2006), beetles (Schloss 
et al. 2006), and ants ( $\mathrm{Li}$ et al. 2005). In contrast, Staphylococcus is not so frequently isolated from insect guts as Bacillus and Enterococcus. No gram-negative proteolytic bacteria were isolated from the gut of $A$. gemmatalis, unliked Cydia pomonella L. (Lepidoptera: Tortricidae) (Ertürk and Demirbag 2006).

The gut bacteria isolated from caterpillars of $A$. gemmatalis were able of hydrolyzing azocasein and L-BApNA in the presence of benzamidine, showing cysteine protease activity. In addition, all isolates exhibited serine protease activity, except S. xylosus. B. cereus showed the highest activity of serine and cysteine proteases, which is not a surprise because most of the commercially available serine proteases are produced by microorganisms from the genus Bacillus (Olajuyigbe and Ajele 2005).

Our data indicate that proteases found in the gut of A. gemmatalis are produced both by the insect and by part of the resident microbiota. Besides of providing an important contribution to the understanding of the insect-microorganism interaction, our results suggest a potential role of these gut bacteria from velvetbean caterpillars in allowing the adaptation of this insect pest species to hosts rich in protease inhibitors, such as soybean. However, the purification and characterization of the gut bacteria protease are still necessary to recognize if indeed they are not inhibited by the soybean protease inhibitors (unlike the gut proteases of the velvetbean caterpillars) and may therefore minimize the effect of such inhibitors in caterpillars of $A$. gemmatalis. This information has pest management implications because it may allow the recognition of the host range of this insect species, is likely to be helpful in defining suitable mimetic analogs of protease inhibitors for use as bioinsecticides, and may also be helpful in guiding soybean breeding programs in developing varieties resistant to its main pest species.

\section{Acknowledgments}

The authors acknowledge the financial assistance provided by the National Council of Scientific and Technological Development (CNPq), CAPES Foundation (Brazilian Ministry of Education), and the Minas Gerais State Foundation for Research Aid (FAPEMIG). The comments and suggestions provided K. Klepzig and two anonymous referees are also greatly appreciated.

\section{References Cited}

Bradford, M. M. 1976. A rapid and sensitive method for the quantification of microgram quantities of proteins utilizing the principle of protein dye binding. Anal. Biochem. 72: $248-254$.

Brennan, Y., W. N. Callen, L. Christoffersen, P. Dupree, F. Goubet, S. Healey, M. Hernández, M. Keller, K. Li, N. Palackal, et al. 2004. Unusual microbial xylanases from insect guts. Appl. Environ. Microbiol. 70: 3609-3617.

Brune, A., and M. Friedrich. 2000. Microecology of the termite gut: structure and function on a microscale. Curr. Opin. Microbiol. 3: 263-269.

Cruden, D. L., and A. J. Markovetz. 1987. Microbial ecology of the cockroach. Annu. Rev. Microbiol. 41: 617-643.
Erlanger, B. F., N. Kokowsky, and W. Cohen. 1961. The preparation and properties of two new chromogenic substrates of trypsin. Arch. Biochem. Biophys. 95: 271-278.

Ertürk, O., and Z. Demirbag. 2006. Studies on bacterial flora and biological control agent of Cydia pomonella L. (Lepidoptera: Tortricidae). Afr. J. Biotechnol. 5: 20812085.

Fortunato, F. S., M.G.A. Oliveira, M.H.N. Brumado, C.H.O. Silva, R.N.C. Guedes, and M. A. Moreira. 2007. Lipoxygenase-induced defense of soybean varieties to the attack of the velvetbean caterpillar (Anticarsia gemmatalis Hübner). J. Pest. Sci. 80: 241-247.

Hoffman-Campo, C. B., E. B. Oliveira, and F. Moscardi. 1985. Criação massal de lagarta da soja (Anticarsia gemmatalis). EMBRAPA-CNPSo, Londrina, Brazil.

Indiragandhi, P., R. Anandham, M. Madhaiyan, S. Poonguzhali, G. H. Lim, V. S. Saravanan, and T. M. Sa. 2007. Cultivable bacteria associated with larval gut of prothiofos-resistant, prothiofos-susceptible and field-caught populations of diamondback moth, Plutella xylostella and their potential for, antagonism towards entomopathogenic fungi and host insect nutrition. J. Appl. Microbiol. 103: $2664-2675$.

Indiragandhi, P., R. Anandham, M. Madhaiyan, and T. M. Sa. 2008. Characterization of plant growth-promoting traits of bacteria isolated from larval guts of diamondback moth Plutella xylostella (Lepidoptera: Plutellidae). Curr. Microbiol. 56: 327-333.

Kunitz, M. 1947. Crystalline soybean trypsin inhibitor II: general properties. J. Genet. Physiol. 30: 291-310.

Kuzina, L. V., J. J. Peloquim, D. C. Vacek, and T. A. Miller. 2001. Isolation and identification of bacteria associated with adult laboratory Mexican fruit flies, Anastrepha ludens (Diptera: Tephritidae). Curr. Microbiol. 42: 290294.

Li, H., F. Medina, S. B. Vinson, and C. J. Coates. 2005. Isolation, characterization, and molecular identification of bacteria from the red imported fire ant (Solenopsis invicta) midgut. J. Invertebr. Pathol. 89: 203-209.

Macovei, L., and L. Zurek. 2006. Ecology of antibiotic resistance genes: characterization of enterococci from houseflies collected in food settings. Appl. Environ. Microbiol. 72: 4028-4035.

Olajuyigbe, F. M., and J. O. Ajele. 2005. Production dynamics of extracellular protease from Bacillus species. Afr. J. Biotechnol. 4: 776-779.

Oliveira, M.G.A., S. G. De Simone, L. P. Xavier, and R.N.C. Guedes. 2005. Partial purification and characterization of digestive trypsin-like proteases from the velvet bean caterpillar, Anticarsia gemmatalis. Comp. Biochem. Physiol. B 140: 369-380.

Pilon, A. M., M.G.A. Oliveira, and R.N.C. Guedes. 2006. Protein digestibility, protease activity and post-embryonic development of the velvetbean caterpillar Anticarsia gemmatalis exposed to the trypsin-inhibitor benzamidine. Pest. Biochem. Physiol. 86: 23-29.

Pompermayer, P., W. R. Terra, J.R.P. Parra, M. C. Falco, and M. C. Silva-Filho. 2001. Effects of soybean proteinase inhibitor on development, survival and reproductive potential of the sugarcane borer, Diatraea saccharalis. Entomol. Exp. Appl. 99: 79-85.

Pospiech, A., and B. Neumann. 1995. A versatile quick-prep of genomic DNA from gram positive bacteria. Trends Genet. 11: 217-218.

Reeck, G. R., B. Oppert, M. Denton, M. Kanost, J. E. Baker, and K. J. Kramer. 1999. Insect proteinases, pp. 125-148. In V. Turk (ed.), Proteases: new perspectives. Birkhauser, Boston, MA. 
Schloss, P. D., I. Delalibera, J. Handelsman, and K. F. Raffa. 2006. Bacteria associated with the guts of two woodboring beetles: Anoplophora glabripennis and Saperda vestita (Cerambycidae). Environ. Entomol. 35: 625-629.

Sneath, P.H.A., N. S. Mair, M. E. Sharp, and G. J. Holt (eds.) . 1986. Bergey's manual of systematic bacteriology 2. Willians \& Wilkins, Baltimore, MD.

Terra, W. R., and C. Ferreira. 2005. Biochemistry and digestion, pp. 171-224. In L. I. Gilbert, K. Iatrou, and S. S. Gill (eds.), Comprehensive molecular insect science, vol. 4. Pergamon, New York.

Walker, A. J., D. M. Glen, and P. R. Shewry. 1999. Bacteria associated with the digestive system of the slug Deroceras reticulatum are not required for protein digestion. Soil Biol. Biochem. 31: 1387-1394.

Wenzel, M., I. Schönig, M. Berchtold, P. Kämpfer, and H. König. 2002. Aerobic and facultatively anaerobic cellulolytic bacteria from the gut of the termite Zootermopsis angusticollis. Lett. Appl. Microbiol. 92: 32-40.

Xavier, L. P., M.G.A. Oliveira, R.N.C. Guedes, A. V. Santos, and S. G. De Simone. 2005. Trypsin-like activity of membrance-bound midgut proteases from Anticarsia gemmatalis (Lepidoptera: Noctuidae). Eur. J. Entomol. 102: 147153.

Received 19 December 2008; accepted 5 May 2009. 